\section{Indole-3-butyric Acid Improves Root System Quality in Guarana Cuttings}

\author{
Karla Gabrielle Dutra Pinto, Sônia Maria Figueiredo Albertino, \\ Bruna Nogueira Leite, Daniel Oscar Pereira Soares,
} Francisco Martins de Castro, Laís Alves da Gama, and Débora Clivati Department of Animal and Plant Production, Universidade Federal do Amazonas, Av. Dr. Rodrigo Octávio Jordão, 1200, Coroado I, Manaus, Amazonas, Brazil 69067-005

\section{André Luiz Atroch \\ Empresa Brasileira de Pesquisa Agropecuária, Centro de Pesquisa Agroflorestal da Amazônia Ocidental, Cpaa. Rodovia AM-010, KM 30, Manaus, Amazonas, Brazil 69011-970 \\ Additional index words. cutting, growth regulator, Paullinia cupana, propagation, rooting}

et al., 2012). Moreover, microdoses of IBA require precision technology, which is unaffordable for Amazonian smallholder guarana farmers who produce without much technology using cultivation techniques that include traditional practices and popular knowledge and in a small area. Therefore, we assessed the quantitative and qualitative variables of root development for stem cuttings of guarana plants treated with different concentrations of IBA to evaluate whether exogenous auxin is useful for this purpose. We showed that no dose of IBA increased the rooting percentage; however, some doses increased the root system quality of the guarana plant cuttings. This is suitable for guarana seedling production by Amazonian smallholder farmers, nurseries, or even large guarana-producing companies.

\section{Materials and Methods}

Propagation experiments. We collected 600 herbaceous stems from three guarana cultivars: BRS Amazonas, BRS-CG372, and BRS-CG611; there were 200 cuttings of each cultivar from healthy plants from the experimental field of Embrapa Amazônia Ocidental, Manaus, Amazonas. Cuttings had variable lengths from 15 to $20 \mathrm{~cm}$ because of the high morphological variability of the different cultivars. We discarded too young, too old, and woody stem cuttings. Stems were placed in a cooler, transported to the greenhouse, and processed on the same day of their collection. Each stem cutting had one pair of leaflets cut in half to avoid dehydration by transpiration. Basal ends of cuttings were dipped in dry powder with $0,1000,2000,3000$, and $4000 \mathrm{ppm}$ of IBA. Cuttings were subsequently planted in $23-\mathrm{cm} \times 18-\mathrm{cm} \times 0.15-\mathrm{mm}$ plastic bags with 24 holes with diameters of $5 \mathrm{~mm}$ to drain excess water. Plastic bags were filled with substrate compound with wild forest soil and sand in a proportion of $4: 1$. We added $3 \mathrm{~kg}$ of regular superphosphate for each $1 \mathrm{~m}^{3}$ of substrate. After filling the plastic bags with the substrate, we placed a thin layer $(1-2 \mathrm{~cm})$ of sand. Plastic bags were placed in a bed over a 10$\mathrm{cm}$-thick layer of pebbles with a $10 \%$ slope to facilitate drainage. The experiment was conducted as a $3 \times 5$ fully random factorial design with 15 treatment combinations and 4 repetitions with 10 cuttings, with a total of 40 cuttings per experimental plot. Three cultivars of guarana tree (BRS-Amazonas, BRS-CG372, and BRSCG611) and five doses of IBA were used. Cuttings were placed in a constant misting system that was controlled by evaporation weigh; it was triggered according to the transpiration of plants.

Environment conditions. The experiment was conducted on a plant bed with $70 \%$ shading and natural temperatures and photoperiods (not controlled). Temperatures and humidity were obtained using a digital thermo-hygrometer (Thermo-Hygrometer Digital, Incoterm 7666.02.0.00; Hospinet 
Table 1. Averages of the percentage of root formation and cuttings with callus and dead cuttings and averages of the length, number, volume, and weight of dry matter of the roots of cuttings of three guarana cultivars regardless of the application of indole-3-butyric acid.

\begin{tabular}{|c|c|c|c|c|c|c|c|}
\hline \multirow[b]{2}{*}{ Cultivar } & \multirow[b]{2}{*}{ Rooted (\%) } & \multirow[b]{2}{*}{ With callus (\%) } & \multirow[b]{2}{*}{ Dead (\%) } & \multicolumn{4}{|c|}{ Averages } \\
\hline & & & & $\begin{array}{l}\text { Length }(\mathrm{cm}) \\
\end{array}$ & Number & Volume (mL) & Dry matter weight (g) \\
\hline BRS-CG611 & $57.00 \mathrm{a}$ & $9.50 \mathrm{~b}$ & $33.50 \mathrm{a}$ & $16.86 \mathrm{a}$ & $14.60 \mathrm{~b}$ & $1.30 \mathrm{~b}$ & $0.28 \mathrm{~b}$ \\
\hline
\end{tabular}

${ }^{\mathrm{z}}$ Means followed by the same letters in each column do not differ at $P=0.5$ according to the Tukey test.

A

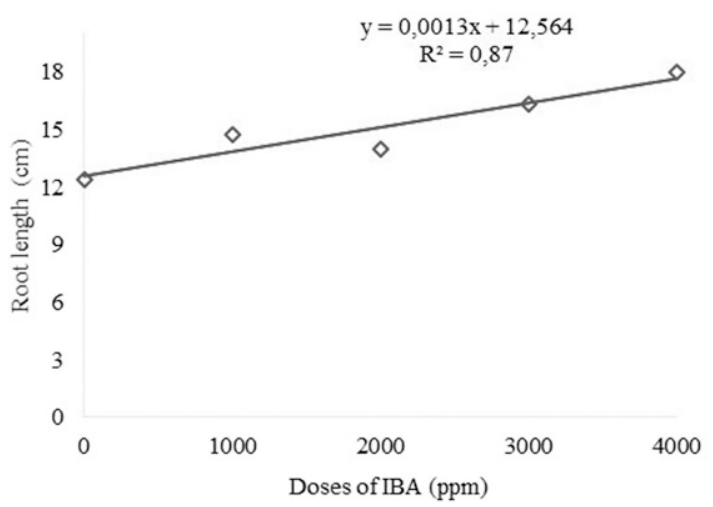

$\mathrm{C}$

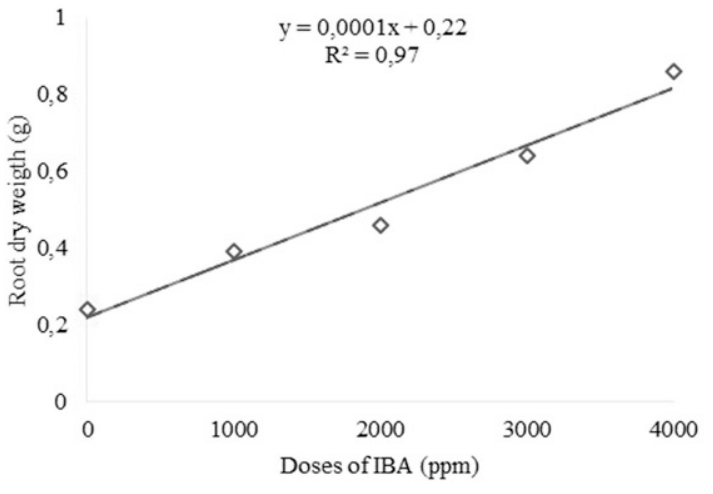

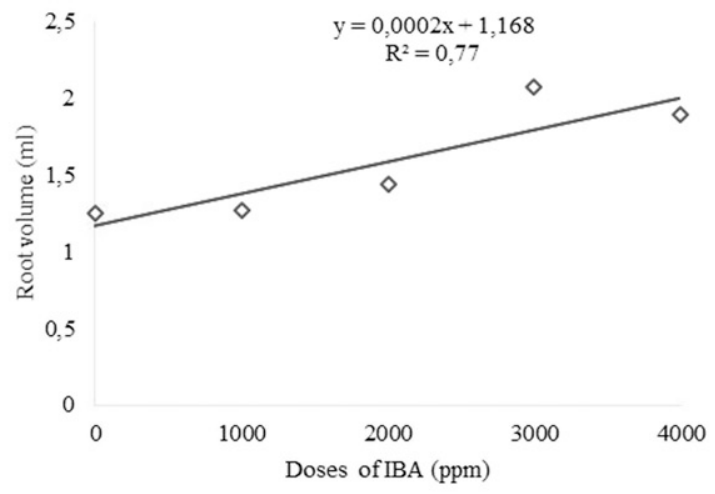

$\mathrm{D}$

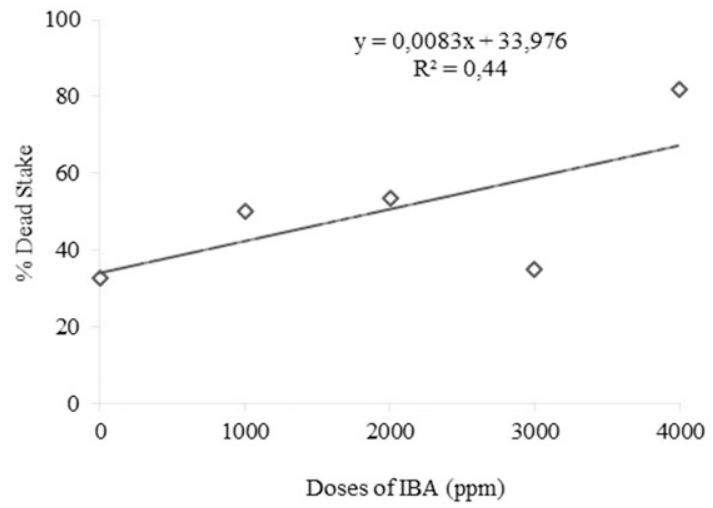

Fig. 1. Regression graphs showing the (A) root length, $(\mathbf{B})$ root volume, $(\mathbf{C})$ root dry matter weight, and (D) percentage of dead cuttings (\%) of guarana cuttings submitted to five doses of indole-3-butyric acid (IBA).

Produtos Médicos e Hospitalares, Curitiba-PR, Brazil) located near the height of the cuttings.

Data collection and analysis. Cuttings were evaluated $90 \mathrm{~d}$ after planting, when propagation success and root system quality were assessed. First, cuttings were uprooted and rinsed gently to remove substrate. Each cutting was rated based on the success of propagation according to Atroch (2007) and classified as follows: class 1 , easy rooting ( $>80 \%$ of cuttings rooted); class 2 , intermediate rooting $(\approx 50 \%)$; class 3 , difficult rooting (30\% to $40 \%)$; and class 4 , bad rooting $(<30 \%)$. These classes were assigned to all cuttings that survived and formed at least one adventitious root at least $1 \mathrm{~cm}$ in length. Dead stem cuttings and cuttings with callus were also counted. Then, the entire root system was removed at the base of insertion on the stem cutting, dried to a constant weight in a hot drying room at $70{ }^{\circ} \mathrm{C}$, and weighed to determine root dry weights using a digital precision scale. Roots were counted and measured with a ruler; then, the average length was calculated per the experimental unit. Root volume was determined by water displacement introducing roots in graduated beakers. The dry weight of the roots was obtained with a precision digital scale. Data analysis was conducted using the statistical software GENES version 2015 5.0 (Cruz, 2001) and Assistat 7.7 (Silva and Azevedo, 2016). Percentage data were analyzed by transforming $\sqrt{\mathrm{x}}+0.5$ to approximate the data to a normal distribution. We used the Lillifors test to assess data normality and homogeneity. Then, we analyzed the data variance; the averages were compared using the Tukey test with $5 \%$ probability. Descriptive statistics (mean and SD) were calculated for each measured parameter. The significant variables for IBA doses and the significant interactions for cultivar and IBA dose were used in the regression analysis adopting the linear model. To select the equation, the significance of the $\mathrm{F}$ test, the value of the coefficient of determination, and the best fit equation for the original data combined with the biological explanation of the characteristic were considered. The results of each factor were presented and discussed individually and with their significant interactions.

\section{Results}

Rooting classification. The cultivars BRS-CG372 and BRS-CG611 had the highest percentages of root formation but also the highest cutting mortality; therefore, they were classified as class 2 (intermediate rooting). The BRS Amazonas cultivar, however, had the lowest cuttings mortality and 
Root system quality. A high-quality root

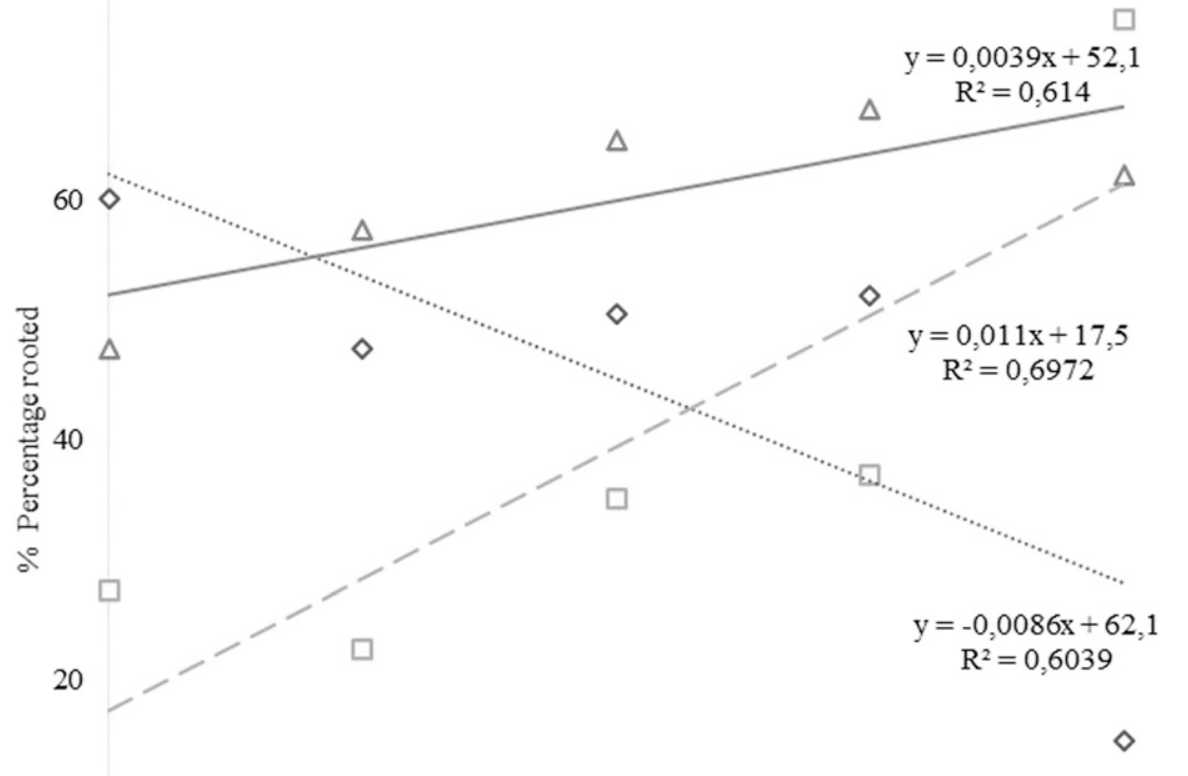

0 0 1000 2000 3000 Doses of IBA (ppm)

$\begin{aligned} \diamond & \text { BRS-CG372 } & \square & \text { BRS-Amazonas } \\ \Delta & \text { BRS-CG611 } & \cdots \cdots \cdots \cdot \text {..... } & \text { Linear (BRS-CG372) } \\ -- & \text { Linear (BRS-Amazonas) }) & & \text { Linear (BRS-CG611) }\end{aligned}$

Fig. 2. Regression graphs of the percentage of rooted cuttings from three guarana cultivars with different doses of indole-3-butyric acid (IBA).

the highest percentage of callus formation (Table 1); therefore, it was classified as a late cultivar.

Root system quality. The root system quality of the cultivar BRS-CG372 had the highest evaluated variables, except the root length, which was similar to that of BRSCG611 (Table 1). When subjected to the five concentrations of IBA, the variables of root length, root volume, and root dry weight increased with increasing doses; however, the number of dead cuttings also increased (Fig. 1).

Cultivar vs. IBA. Responses were different between cultivars for each phytohormone dose. The cultivar BRS-CG611 had the highest rooting in all applied doses, including the control treatment, without IBA (Fig. 2). The root volume varied between cultivars with each dose of IBA. Without IBA, the cultivar BRS Amazonas had the lowest volume. At $1000 \mathrm{ppm}$, there was no significant difference in root volumes among cultivars; at 2000 ppm, the root volume of BRS Amazonas was also lower than that of the others cultivars; at $3000 \mathrm{ppm}$, only the volume of cultivar BRS-CG372 was higher; and at 4000 ppm, the volume of BRS-CG611 was lower than that of all the cultivars (Fig. 3). The aver- age temperature during the experiment was $33{ }^{\circ} \mathrm{C}$ and the relative humidity averaged $70 \%$ (Fig. 4).

\section{Discussion}

Rooting classification. The root formation of guarana stem cuttings is highly unstable, varying between $5.6 \%$ and $90.6 \%$ among cultivars (Albertino et al., 2012; Arruda et al., 2007). The formation of roots starts with the swelling of the basal end, forming a callous tissue where the cells undergo progressive differentiation and constitute the root system of the cutting (Benda et al., 1960); this is the process that occurs in guarana cuttings. The possibility of adventitious rooting increases as the acceleration of this process increases (Dias et al., 2012). The percentage of rooting of BRS-CG611 corresponds to the intermediate class (Table 1). Similar results were found by Atroch et al. (2007), with $67.89 \%$ of rooted cuttings. However, the results are higher than those described by Arruda et al. (2007), who found $41.40 \%$ of rooted cuttings, probably because their experiment was conducted in small tubes $\left(250 \mathrm{~cm}^{3}\right)$ with less space for root growth and development. system provides greater plant support and greater field survival. Therefore, the number and length of roots, in addition to the percentage of rooted cuttings, are the most relevant variables for seedling production (Lopes et al., 2015). A larger number of physiologically active roots and a larger root surface area are reflected in the exploration of a larger volume of soil, positively influencing production due to the greater capacity of plants to adapt to the environment under adverse conditions (Borcioni et al., 2016). Although root length is used to determine root density and growth (Benedetti et al., 2017), cuttings with larger roots are more likely to lose or damage seedling transposition. Depending on the concentration and the time of exposure to auxin, tissue growth and differentiation are inhibited or stimulated with optimal levels for these physiological responses (Alarcón et al., 2013). Therefore, the addition of IBA increased the root length (Fig. 1A).

The root volume increased proportionally with the increase in IBA doses (Fig. 1B). The maximum volume point was reached with the highest dose of IBA, with an increase of $\approx 38 \%$, regardless of the cultivar. The increased root volume can enhance plant nutrition and support (Moreira et al., 2013). The accumulation of dry matter in the roots also increased with the addition of IBA; however, the nutritional status of the stock plant of the cutting also directly influences this variable (Galindo et al., 2018). Cell division promoted by the hormonal balance increases the fresh and dry mass of roots, indicating better absorption of nutrients (Fig. 1C) (Neumann et al., 2018). The higher dry matter weight of the cultivar BRS-CG372 (Table 1) may be related to the greater number and length of roots. However, redirection of assimilates to other activities, such as the large production of callus, may have decreased the roots dry biomass of the BRS Amazonas cultivar (Steffen et al., 2011). Our positive results indicate the efficiency of IBA to improve the root system quality of guarana plant cuttings and, consequently, help the establishment of the seedling in the field and plant development (Silva et al., 2012).

Although IBA application contributed to increase the root system quality, it reduced the rooting percentage, thereby causing the mortality of cuttings (Fig. 1D). The highest percentage of rooting and the lowest mortality rate of guarana plant cuttings are obtained without the application of IBA, regardless of the cultivar (Rodrigues and Lucchesi, 1987).

Cultivar $\times I B A$. The auxin concentration can be abundant, scarce, or absent in plant tissues according to the physiological condition and genetic variability of the cuttings among and within cultivars (Atroch et al., 2007; Pizzatto et al., 2011), resulting in different responses of cultivars at different doses of IBA (Fig. 2). This may be the case for the BRS-CG372 cultivar, which rooted without IBA. Exogenous auxin may be toxic 


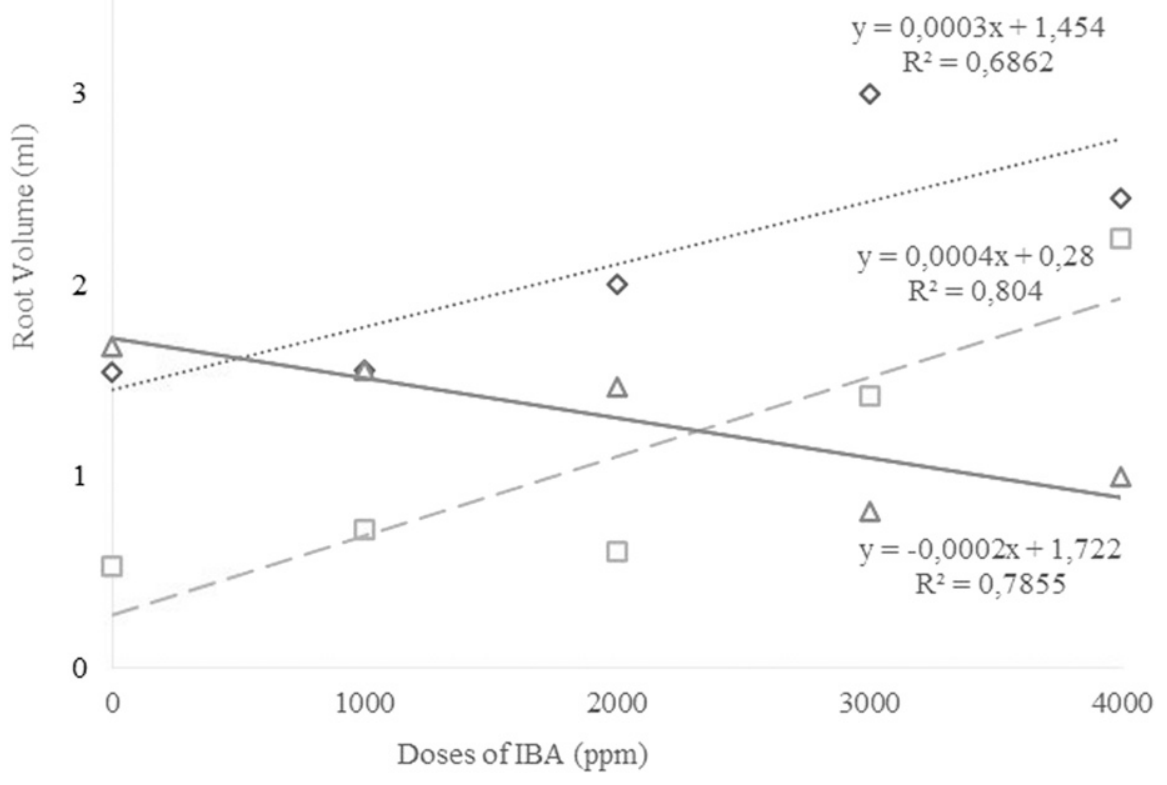

$\diamond \quad$ Cultivar BRS-372

$\triangle$ Cultivar BRS-611

- - Linear (Cultivar BRS-Amazonas) Linear (Cultivar BRS-611)

Fig. 3. Regression graphs of the root volume $(\mathrm{RV} ; \mathrm{mL})$ of cuttings from three guarana cultivars with different doses of indole-3-butyric acid (IBA).

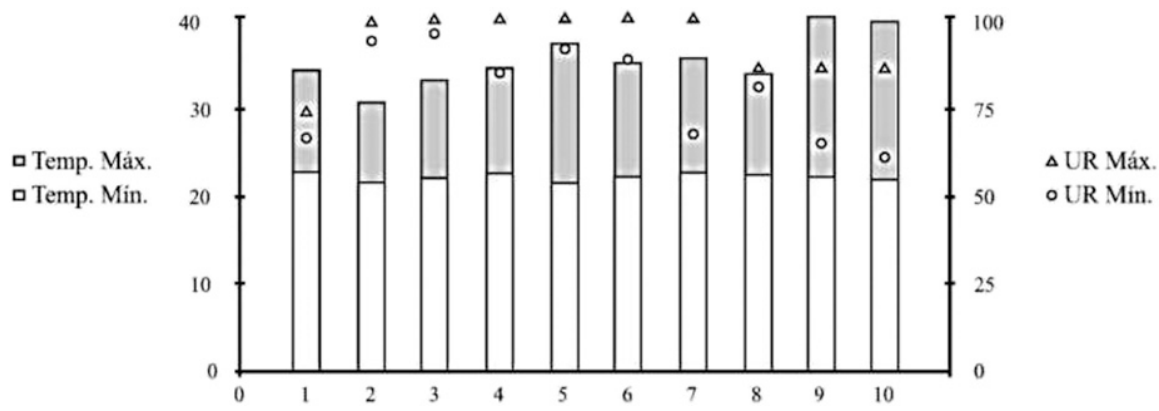

Fig. 4. Averages of the minimum and maximum temperatures and minimum and maximum relative humidity during the rooting of guarana cuttings.

to this cultivar because we observed that higher IBA doses resulted in lower rooting percentages. This mechanism is welldescribed because inducers can stimulate the roots up to a maximum value, and eventual increases from that point can produce toxic effects (Inocente et al., 2018). In contrast, the BRS Amazonas cultivar had a higher percentage of rooted cuttings using the highest dose of IBA.

When a natural imbalance of auxin levels is found, the exact dose of exogenous regu- level of endogenous auxin in the stretching region is close to the optimum point; alternatively, inhibition can be attributed to ethylene biosynthesis induced by auxin (Alarcón et al., 2013). Therefore, the use of synthetic auxin, such as IBA, can induce adventitious root formation, thus increasing the rooting percentage because cuttings at different points of physiological maturation can present different responses in relation to rooting (Winhelmann et al., 2018). Other factors must be considered for good rooting, such as physiological conditions, the growth habits of the plant, and environmental factors (water availability, substrates, light, temperature, and relative humidity) (Denaxa et al., 2012). In this context, the high temperatures (average of $33{ }^{\circ} \mathrm{C}$ ) observed during this experiment may have favored the loss of water from the stem cuttings, thus impairing their rooting and survival (Fig. 4). However, cell division is favored by the temperature increase, which helps the formation of roots and the production of shoots, and the high temperatures also increase transpiration and water loss by the leaves (Paiva et al., 2009). However, low temperatures decrease the metabolism of cuttings, leading to less production of sprouts and longer times for rooting, or do not provide appropriate conditions for induction, development, and root growth (Corrêa and Fett-Neto, 2004). The ideal average temperature range for rooting cuttings of most species is 21.1 to $26{ }^{\circ} \mathrm{C}$, whereas the ideal air humidity is $80 \%$ to $100 \%$, which allows the maintenance of the turgor of the tissue and survival (Benda et al., 1960). The avoidance of critical moisture levels, especially for cuttings with leaves, prevents the risk of dehydration and death before root formation (Zang et al., 2013). Nevertheless, the intermittent overhead mist system allowed the maintenance of $70 \%$ average humidity, thus protecting the leaf surfaces from dehydration. The intermediate to low rooting percentages (BRS-CG372 49\%, BRS-CG611 57\%, and BRS Amazonas $31.50 \%$ ) might have been influenced by this environmental factor and genetic factors.

We demonstrated that IBA does not affect the rooting of guarana stem cuttings. Even though cultivars show different rooting capacities, all guarana cultivars rooted without exogenous IBA. Therefore, clonal production by stem cuttings can use rooting inducers for this purpose, allowing Amazonian smallholder farmers to produce guarana plant seedlings at reduced costs. Furthermore, the production of other species by cuttings also does not require IBA for rooting, such as some vine cultivars (Faria et al., 2007; Lone et al., 2010b; Machado et al., 2005), azalea (Lone et al., 2010a), different eucalyptus clones (Almeida et al., 2007), and mini-cuttings of purple ipê (Oliveira et al., 2015).

\section{Literature Cited}

of these regulators (such as IBA) does not influence the development of the root or aerial system of the seedlings (Lafetá et al., 2016). This null stimulus to the growth of the propagating material can occur when the

lators must be investigated to optimize rooting without burdening the seedling production process. These regulators affect Fig. g. 3), thus influencing seedling development and survival to transplanting (Lima

Alarcón, M.V., P.G. Lloret, and J. Salguero. 2013. Auxin-ethylene interaction in transversal and longitudinal growth in maize primary root. Botany 91:680-685. 
Albertino, S.M.F., F.J. Nascimento Filho, J.F. Silva, A.L. Atroch, and A.L. Lima Galvão. 2012. Rooting of guarana cultivar cuttings with fertilization of matrix plants. Enraizamento de estacas de cultivares de guaranazeiro com adubação de plantas matrizes. Revista Pesquisa Agropecuária Brasileira 47:1449-1454.

Almeida, F.D.D., A. Xavier, J.M.M. Dias, and H.N. Paiva. 2007. Auxin (IBA and NAA) effects on minicuttings rooting of Eucalyptus cloeziana $\mathrm{F}$. Muell. Clones.Muell. Eficiência das auxinas (AIB e ANA) no enraizamento de miniestacas de clones de Eucalyptus cloeziana F. Muell. Rev. Arvore 31:455-463.

Angelo, P.C.S., M.P.S. Lira, M.V. Amado, A.T. Yamaguishi, G.F. Silva, J.I.R. Porto, and A.L. Atroch. 2014. Microsatellites and the polyploid guarana plant: diversity under a sea of alleles. Open J. Genet. 04:190-201.

Arruda, M.R., J.C.R. Pereira, A. Moreira, and W. Teixeira. 2007. Survival rate of guarana herbaceous cuttings in different substrates. Enraizamento de estacas herbáceas de guaranazeiro em diferentes substratos. Cienc. Agrotec. 31:236241.

Atroch, A.L., M.S. Cravo, and J.A. Santos. 2007. Rooting of guarana clones cuttings treated with indole-3-butyric acid (IBA). Enraizamento de clones de guaranazeiro tratados com ácido Indol-3-Butírico (AIB). Revista de Ciências Agrárias 47:103-112. <http://ajaes.ufra.edu.br/ index.php/ajaes/article/view/198/88>.

Azevedo, G.T.O.S., A.M. Souza, G.B. Azevedo, and P.H.A. Cerqueira. 2015. Minicutting rooting of eucalyptus with different doses of the hydrophylic polymer incorporated into the substrate. Enraizamento de mini estacas de eucalipto com diferentes doses de polímero hidroretentor incorporado ao substrato. Scientia Florestalis, Piracicaba 43:773-780.

Benda, G.T.A., H.T. Hartmann, and D.E. Kester. 1960. Plant propagation: principles and practices. Amer. Midl. Nat., doi: 10.2307/2422951.

Benedetti, E.L., D. Santin, N.F. Barros, G.L. Pereira, H.P. Martinez, and J.C.L. Neves. 2017. Does Aluminum stimulate mate root growth? Alumínio estimula o crescimento radicular de erva-mate? Pesqui. Florest. Bras. 37:139-147.

Borcioni, E., Á.F. Mógor, and F. Pinto. 2016. Influence of the application of fulvic acid on seedling root growth and yield in lettuce. Aplicação de ácido fúlvico em mudas influenciando o crescimento radicular e produtividade de alface americana. Rev. Cienc. Agron. 47:509-515.

Clement, C.R., M. Cristo-Araújo, G.C. d'Eeckenbrugge, A.A. Pereira, and D. Picanço-Rodrigues. 2010. Origin and domestication of native amazonian crops. Diversity 2:72-106.

Corrêa, L.D.R. and A.G. Fett-Neto. 2004. Effects of temperature on adventitious root development in microcuttings of Eucalyptus saligna Smith and Eucalyptus globulus Labill. J. Thermal Biol. 29(6):315-324.

Cruz, C.D. 2001. GENES Program: Computational Application in Statistics Applied to Genetics. Programa GENES - versão windows. Aplicativo computacional em Genética e Estatística. 1. ed. Viçosa, UFV.

Denaxa, N.K., S.N. Vemmos, and P.A. Roussos. 2012. The role of endogenous carbohydrates and seasonal variation in rooting ability of cuttings of an easy and a hard to root olive cultivars (Olea europaea L.). Scientia Hort. 143:19-28.

Dias, P.C., A. Xavier, L.S.D. Oliveira, H.N.D. Paiva, and A.C.G. Correia. 2012. Vegetative propagation of angico-vermelho Anadenanthera macrocarpa (Benth) Brenan) half-sibs by mini-cuttings. Propagação vegetativa de progênies de meios-irmãos de angico-vermelho (Anadenanthera macrocarpa (Benth) Brenan) por miniestaquia. Rev. Arvore 36:389-399.

Faria, A.P., S.R. Roberto, A.J. Sato, E.B Rodrigues, J.V. Silva, P.J.D. Sachs, and L.K. Unemoto. 2007. Rooting of semi hardwood cuttings of 'IAC 572 - Jales' grapevine rootstock treated with different concentrations of indolbutyric acid. Enraizamento de estacas semilenhosas do porta-enxerto de videira 'IAC 572-Jales' tratadas com diferentes concentrações de ácido indolbutírico. Semin. Cienc. Agrar. 28:393-398.

Galindo, F.S., S. Buzetti, M.C.M. Teixeira Filho, E. Dupas, and M.G.Z. Ludkiewicz. 2018. Dry matter and nutrients accumulation in mombasa guineagrass in function of nitrogen fertilization management. Acúmulo de matéria seca e nutrientes no capim-mombaça em função do manejo da adubação nitrogenada. J. Neotropical Agr. 5:1-9.

Gama, L.A., K.G.D. Pinto, B.N. Leite, G.S Gonçalves, J.O. Pereira, J.F. Silva, and S.M.F. Albertino. 2019. Rizobacteria isolated in the Amazon and its influence on the growth of guarana seedlings. J. Agr. Sci. 11:4.

Inocente, V.H.H., A.A. Nienow, and L. Tree. 2018. Time of treatment with IBA in Olive cultivars rooting. Rev. Bras. Frutic. 40, doi: 10.1590/ 0100-29452018800.

Lafetá, B.O., M.P. Matos, P. Lage, A.C. Ferraro, and T.M.A. Penido. 2016. Indol-3-butyric acid (IBA) in rooting of fedegoso gigante cuttings. Ácido indol-3-butírico (AIB) no enraizamento de estacas de fedegoso gigante. Pesqui. Florest. Bras. 36:489-496.

Lima, C.C., S.T. Ohashi, and A.S. Silveira. 2018. Effect of concentration of different iba and origins geographical in parica stakes of rooting. Efeito de diferentes concentrações de AIB e procedências geográficas no enraizamento de estacas de paricá. Cienc. Florest. 28:1282-1292.

Lone, A.B., L.K. Unemoto, L.Y. Yamamoto, L. Costa, J.A. Schnitzer, A.J. Sato, and S.R. Roberto. 2010a. Rooting of azalea cuttings (Rhododendron simsii Planch.) in the fall of IBA and different substrates. Enraizamento de estacas de azaleia (Rhododendron simsii Planch.) no outono em AIB e diferentes substratos. Cienc. Rural 40:1720-1725.

Lone, A.B., E.L. López, S.R.S. Rovaris, D.F. Klesener, L. Higashibara, L.T. Ataíde, and S.R. Roberto. 2010b. Effects of substrates and IBA on the rotting of herbaceous cuttings of VR 43-43 grapevine rootstocks. Efeito do AIB no enraizamento de estacas herbáceas do porta-enxerto de videira VR 43-43 em diferentes substratos. Semin. Cienc. Agrar. 31:599-604.

Lopes, E.D., C.L.F. Amaral, and A.B. Novaes. 2015. Morphophysiological parameters in the evaluation of seedling quality of three forest species. Parâmetros morfofisiológicos na avaliação da qualidade de mudas de três espécies florestais. Revista Agrogeoambiental 8:3.

Machado, M.P., J.L.S. Mayer, M. Ritter, and L.A. Biasi. 2005. Indole butyric acid on rooting ability of semihardwood cutting of grapevine rootstock 'VR 043-43' (Vitis vinifera $\mathrm{x}$ Vitis rotundifolia). Ácido indolbutírico no enraizamento de estacas semilenhosas de porta-enxerto de videira 'VR043-43' (Vitis vinifera x Vitis rotundifolia). Rev. Bras. Frutic. 27:476-479.

Moreira, L.C.B., J.M.R. Reis, C.V. Mota Júnior, C.G. Caixeta, and E.J. Canedo. 2013. Seedling production of golden passion fruit with the use biofertilizer and cattle manure in substrate. Produção de mudas de Maracujazeiro Amarelo com utilização de supermagro e esterco bovino no substrato. Global Sci. Technol. 6:12-22.

Neumann, E.R., J.T.V. Resende, L.P. Camargo, R.R. Chagas, and R.B. Lima Filho. 2018. Production of sweet potato seedlings in protected environment with the application of Ascophyllum nodosum extract. Produção de mudas de batata-doce em ambiente protegido com aplicação de extrato de Ascophyllum nodosum. Hort. Bras. 35:490-498.

Oliveira, T.P.D.F., D.G. Barroso, K.R. Lamônica, V.S. Carvalho, and M.A. Oliveira. 2015. Effect of indol-3- butiric acid (IBA) on the rooting of "Ipê-Roxo" (Handroanthus heptaphyllus Mattos) minicuttings. Efeito do ácido indol-3butírico (AIB) no enraizamento de miniestacas de ipê-roxo (Handroanthus heptaphyllus Mattos). Cienc. Florest. 25:1043-1051.

Pacurar, D.I., I. Perrone, and C. Bellini. 2014. Auxin is a central player in the hormone crosstalks that control adventitious rooting. Physiol. Plant. 151:83-96.

Paiva, H.N., H.G. Leite, N.F. Barros, and F.P. Leite. 2009. Influence of the nutritional status of ministumps on the rooting of eucalypt minicuttings. Influência do estado nutricional de minicepas no enraizamento de miniestacas de eucalipto. Rev. Arvore 33:607-615.

Pinto, C.E.D.L., A.L. Atroch, J.D.V. Fajardo, and F.J. Nascimento Filho. 2018. Selection of guarana clones for adaptability and stability in the state of Amazonas. Seleção de clones de guaranazeiro para adaptabilidade e estabilidade no estado do Amazonas. Rev. Cienc. Agrar. 61, doi: $10.22491 /$ rca.2018.2558.

Pizzatto, M., A.W. Júnior, D. Luckmann, K. Pirola, D.A. Cassol, and S.M. Mazaro. 2011. Influence of the use of IBA, time of collection and cutting size on the vegetative propagation of hibiscus by cuttings. Ceres $58: 4$

Ramos, J.D., L.E.S. Matos, T.C.A. Gontijo, R. Pio, K.P. Junqueira, and F.C. Santos. 2003. Rooting of herbaceous cuttings of 'mirabolano' (Prunus cerasifera ehrn) using different substrates and concentrations of indol butiric acid. Enraizamento de estacas herbáceas de'Mirabolano' (Prunus cerasifera Ehrn) em diferentes substratos e concentrações de ácido indolbutírico. Rev. Bras. Frutic. 25:189-191.

Rodrigues, J.E.L. and A.A. Lucchesi. 1987. Vegetative propagation of guarana plant (Paullinia cupana (Mart.) Ducke) by cuts root induced with indolilbutiric acid. Propagação vegetativa do guaranazeiro (Paullinia cupana (Mart.) Ducke) através de estacas induzidas (capeadas) e com ácido indolilbutírico. An. Esc. Super. Agr. Luiz de Queiroz 44:1-20.

Schimpl, F.C., J.F. Silva, J.F. Carvalho Gonçalves, and P. Mazzafera. 2013. Guarana: Revisiting a highly caffeinated plant from the Amazon. J. Ethnopharmacol. 150:14-31.

Silva, F.D.A.E. and C.D. Azevedo. 2016. The Assistat Software Version 7.7 and its use in the analysis of experimental data. Afr. J. Agr. Res. 11:3733-3740.

Silva, F.V.G.D., S.D.M. Silva, G.C.D. Silva, R.M.N. Mendonça, R.E. Alves, and A.L. Dantas. 2012. Bioactive compounds and antioxidant activity in fruits of clone and ungrafted genotypes of yellow mombin tree. Food Sci. Technol. 32:685-691.

Soares, D.O.P., S.M.F. Albertino, F.C.P. Souza, A.F. Santos, and J.F. Silva. 2019. Period of weed interference in guarana crop. Planta Daninha 37, doi: 10.1590/s0100-83582019370100070.

Steffen, G.P.K., Z.I. Antoniolli, R.B. Steffen, and G. Schiedeck. 2011. Use of vermicompost as a 
substrate in the production of seedlings Eucalyptus grandis and Corymbia citriodora. Utilização de vermicomposto como substrato na produção de mudas de Eucalyptus grandis e Corymbia citriodora. Brazilian For. Res. 31:66-75.
Winhelmann, M.C., G.T. Grzeça, A.A. Emer, M Tedesco, P. Paris, J. Paolazzi, C.S. Fior, and G Schafer. 2018. Rooting of apical cuttings of Angelonia integerrima Sprengel: Concentrations of indole-3-butyric acid and substrates. Ornam. Hort. 24:109-115.
Zang, W., L. Song, J.A.T. Silva, and H. Sun. 2013. Effects of temperature, plant growth regulators and substrates and changes in carbohydrate content during bulblet formation by twinscale propagation in Hippeastrum vittatum 'Red lion’. Scientia Hort. 160:230-232. 